„Bohemistyka” 2021, nr 2, ISSN 1642-9893

Svatava URBANOVÁ

Ostravská univerzita

\section{Listy lásky, víry a naděje $\mathrm{e}^{1}$}

Jméno Antonína Satkeho (1920-2008), slezského folkloristy, etnografa a jazykovědce, stále více hlasitě připomínáme a citujeme v odborných pracích. Jeho monogra-

${ }^{1}$ Listy lásky, víry a naděje. Editor Kamil Rodan. Opava: Slezské zemské muzeum, 2020. 366 s. ISBN 978-80-87789-70-4. fie Hlučinský pohádkář Josef Smolka (1958), Povidky a humorky ze Slezska (1984), Úsměv a smích. Anekdoty a humorky slezského venkova a hornického Ostravska (1991) a další studie, stati, články nic neztratily na své podnětnosti. „Edice korespondence se snoubenkou, sestrou a dalšími rodinnými př́slušníky od srpna 1957 do května 1962“" nabízí ovšem jiný pohled na Antonína Satka. Je mnohem osobnější. Se zaujetím čteme, jak se formoval milostný vztah dvou mladých lidí, kterým společenským tlakům a perzekucím byla vystavena katolicky smýšlející inteligence na Opavsku. Obětí se stal mj. Antonín Satke, někdejší odborný pracovník Slezského studijního ústavu v Opavě, obviněný z činnosti tzv. Společnosti laiků. Ta údajně měla sdružovat učitele, spisovatele, kněze, lékaře a další věřící jakožto „záškodníky a přisluhovače Vatikánu“. Antonín Satke byl umístěn do vězeňské vazby v Ostravě-Heřmanicích a na podzim 1961 došlo „,k vykonstruovanému procesu s politickým podtextem, ve kterém mu byl vyměřen čtyř a půlletý trest. Nastoupil do vězení v Praze - Pankráci, stejně jako mu byl stanoven vedlejší trest - propadl mu veškerý majetek. Až amnestie prezidenta republiky z počátku května 1962 umožnila Satkeho propuštění na svobodu a složitý návrat do života.“Zvolený název edice Listy lásky, virry a naděje, čítající 160 dopisů, vnímáme jako dvojnásobnou synekdochu. Odvíjí se před námi životní prúiběh v duchu největších křest’anských hodnot a ctností, nebot' vzájemný vztah snoubenců byl založený na hluboké lásce $\mathrm{k}$ bližním, na viře - nejdůležitějšího životního symbolu a na naději, která vedla $\mathrm{k}$ stabilitě postojů. Dopisy se zároveň stávají unikátním svědectvím o osudu dvou obdivuhodných osobností.

Úvodní a závěrečné slovo editora, historika Kamila Rodana, tvoří rámec edice a poslouží k pochopení obsahu dopisů. Editor připomíná osudy dvojice Antonín Satke - Vlasta Kurková, jak se dochovaly v rodinných archivech. Pokud některé dopisy chyběly, nebo byly části vynechány, bylo to způsobeno vězeňskou cenzurou. Editor pak měl k dispozici pouze kopie dopisů. Dopisy jsou řazeny chronologicky a jsou opatřeny podrobným popisem, vysvětlivkami a dílčími edičními poznámkami, dbá se na důsledné dodržování ochrany osobních údajů. Zveřejněné texty zachovávají přirozený dialogický proud, přitom je důležité sdělení, že po dobu ostravské vězeňské vazby bylo Satkemu umožněno psát jeden dopis za 14 dnů a pouze jednomu rodinnému adresátovi. Proto jsou dopisy adresovány sestře Františce Řehulové a jsou do něj vkládány pasáže pro snoubenku Vlastu Kurkovou. Čtenářskou atraktivitu publikace zvyšuje obrazová př́loha, sestávající z kopií soukromé korespondence i úřední pošty, z vybraných rodinných fotografií, které dosud nebyly nikde zveřejněny. Chronologie časová je umocněna číslováním dopisů a oddělováním čarou, aby se zásilka odlišila. Často se jednalo o text $\mathrm{v}$ textu (dopis rodině a dopis snoubence). Upoutá nás nejen datace a lokace, ale zejména oslovení adresátů. Od strohého „Vlasto“ a „Milý pane profesore“, se mění na „Vlastenko“, „Moje milá Vlastenko“, „Moje nejdražší‘, nebo jen 
„Milá“. Z druhé strany se postupně objevuje oslovení Antoníne a u dopisů do vězení převažuje oslovení „Náš nejdražši“", později „Můj nejdražší“.

Vlasta Kurková (1926-2011) a Antonín Satke se seznámili ve Slezském studijním ústavu v Opavě, kde Vlasta jako studentka vypomáhala přepisovat materiály pořízené vědeckými pracovníky, zakládala je a katalogizovala. Již tehdy jí imponovaly Satkeho široké vědomosti, vzhližela $\mathrm{k}$ němu s obdivem a se zaujetím sledovala jím zvolené odborné postupy a př́stupy $\mathrm{k}$ problémům. Ráda ho doprovázela při terénním výzkumu na Hlučínsku a postupně se stávala nejen pomocnicí, ale přímo blízkou spolupracovnicí. Nicméně se po absolvování střední školy zcela racionálně rozhodla pokračovat ve vysokoškolském studiu na Lékařské fakultě Univerzity Palackého v Olomouci, nebot' uchazeči o medicinské obory nebyli tak ostře kádrově posuzováni, jako se tomu dělo u společenskovědního zaměření. Přátelská náklonnost Vlasty a Antonína se postupně měnila v lásku. Stali se snoubenci, po propuštění z vězení v květnu 1962 záhy vstoupili do stavu manželského. Každá korespondence je svým způsobem psychologickou sondou pisatelů. Citově zdrženlivý Antonín Satke se setkal s dívčí vřelostí a empatií, nepředstíraným obdivem a oddaností, s nepodmiňovanou láskou, a vše po svém opětoval. Vlasta se projevuje jako velmi vnímavá a učenlivá bytost, dychtíci po kráse a harmonii, kterou nachází v přírodě a umění. $V$ jejích dopisech do vězení se objevuje mnoho kulturních glos, informace o nově vycházejících knihách, které si zakoupila a přečetla, nechybí reflexe uměleckých zážitků při poslechu hudebních skladeb, uvažování o shlédnutých divadelních představeních a jiné postřehy. Satke reaguje opatrněji, protože ví, že jsou jeho dopisy prověřovány. Nicméně k jednomu z nich připojuje Zahradníčkovu báseň Pozdrav, kterou editor zařadil jako uvozující následující dopisy. Čtenář nikdy nepocítí vnitřní míjení obou mladých lidí, nebot' $\mathrm{k}$ němu nedochází, a to bez ohledu, zda se píše o běžných každodenních činnostech nebo svátečních chvilkách, zmiňují se úsměvné př́hody prožité s dětmi z Antonínovy rodiny, nebo se sdělují dojmy z přátelských návštěv příbuzných z obou stran rozvětvené rodiny Satkových a Kurkových. Nejednou čteme citace z textů vzájemně oblíbených autorů. Zaujme nás, kolik pozornosti věnuje Vlasta chování dětí, jak se rozepisuje o Antonínových synovcích a neteřích. Jako kdyby se již v nich budovalo její odborné zaujetí dětskou psychikou. Dodejme, že se zúročují v její budoucí profesní kariéře, nebot' se později specializuje na dětskou psychiatrii.

Precizně editovaný svazek korespondence je určen odborníkům, avšak určitě v něm najde zalíbení širší čtenářský okruh. K orientaci slouží jmenný seznam př́ibuzných a známých, místopisný slovník, tříjazyčné resumé a zmiňovaná ediční poznámka. Nejcennější se však pro nás stává zjišstění, že publikace umožňuje nahlédnout do nitra dvou pozoruhodných osobností, které musely v realitě své doby doslova procházet trnitou životní cestou. Dokázali zachovat si lidskou důstojnost i odvahu, prokázali nevšední schopnost čelit nespravedlnosti a zlu. Vynucené odloučení posilovalo kvali- tu budovaného vzájemného vztahu a manželství se pro ně stalo prrístavem lásky, víry a naděje. Dodejme, že editora Kamila Rodana natolik zaujala osobnost a dílo Antonína Satkeho, že mu míní nadále věnovat badatelskou pozornost, připravuje životopisnou publikaci, kde jistě najdeme řadu dalších doplňujících faktografických údajů a dojde $\mathrm{k}$ zveřejnění podrobného soupisu literatury a pramenů. 